\title{
'Candidatus Liberibacter solanacearum' haplotypes D and E in carrot plants and seeds in Tunisia
}

\author{
Soukaina Ben Othmen ${ }^{1}$ • Félix E. Morán ${ }^{2}$ Inmaculada Navarro ${ }^{2}$ Silvia Barbé ${ }^{2}$. Carmen Martínez ${ }^{2}$. \\ Ester Marco-Noales ${ }^{2}$ • Brahim Chermiti ${ }^{1}$ • María M. López ${ }^{2}$
}

Published online: 30 April 2018

(C) The Author(s) 2018

\begin{abstract}
Vegetative disorders similar to those associated with the presence of 'Candidatus Liberibacter solanacearum' (CaLsol) were observed in carrot plants in Kairouan, Tunisia from 2014 to 2016. Symptoms including leaf curling, yellowing, bronze and purplish discoloration, stunting of plants and roots, and proliferation of secondary roots, affected 20 to $40 \%$ of the carrots in some plots. In order to determine if these symptoms were associated with the presence of CaLsol, and/or 'Ca. Phytoplasma spp.' and/or Spiroplasma citri, real-time PCR analyses were conducted using specific primers for these pathogens. CaLsol was detected for the first time in Tunisia and for the first time its haplotypes D and E were detected co-infecting a carrot plant. Furthermore, three samples of carrot seed produced in Kairouan tested positive for the haplotype D, showing a high percentage ( 35 to $63 \%$ ) of viable bacterial cells after treatment with propidium monoazide. However, all the tests were negative for ' $\mathrm{Ca}$. Phytoplasma' spp. as well as for S. citri. The results highlight that several CaLsol haplotypes are emerging carrot pathogens in new areas.
\end{abstract}

Keywords 'Ca. Phytoplasma' spp. · Spiroplasma citri · Bactericera sp. · real-time PCR

\section{Introduction}

Carrot is one of the most important crops in Tunisia. The average production is about 215,000 tons per year, from an area of 6319 ha (http://www.agriculture.tn, dates from 2015). The main production area of approximately 1730 ha is located in the centre of the country (Governorate of Sidi Bouzid). In 2014, 2015 and 2016, symptoms similar to those associated with the presence of 'Ca. L. solanacearum' (CaLsol) were observed in the Governorates of Kairouan and Sidi Bouzid and, to a lesser extent, in several other carrot-growing areas such as Fahes (Governorate of Zaghouan) and Chott-Mariem (Governorate of Sousse). According to preliminary surveys, there were around $20 \%$ symptomatic plants during 2014, that

S. Ben Othmen and F.E. Morán are first authors

Félix E. Morán

moran_fel@gva.es

1 High Agronomic Institute of Chott-Mariem, University of Sousse, 4042 Chott-Mariem, Tunisia

2 Instituto Valenciano de Investigaciones Agrarias (IVIA), CV-315 km 10.7, 46113 Moncada, Valencia, Spain increased to $40 \%$ in 2015 and 2016. Symptoms were observed on plants of cultivars grown from local seeds as well as on commercial hybrids such as Maestro, Concerto and Olympus, imported from other continents.

CaLsol belongs to the order Rhizobiales of the $\alpha-2$ subdivision of the Gram-negative Proteobacteria. Species in this bacterial genus alternate hosts in their life cycle between the plant phloem and the psyllid vector hemolymph (Liefting et al. 2009b; Lin et al. 2009) and, with the exception of the new species Liberibacter crescens (Fagen et al. 2014), have not yet been cultivated in axenic medium.

CaLsol is associated with various vegetative disorders in solanaceous crops including eggplant (Solanum melongena), pepper (Capsicum annuum), potato (S. tuberosum), tamarillo (S. betaceum), tobacco (Nicotiana tabacum), tomatillo (Physalis peruviana), tomato (S. lycopersicum), wolfberry (Lycium barbarum), and weeds such as black nightshade (S. ptychanthum) and silver leaf nightshade (S. elaeagnifolium) (EPPO 2013; Haapalainen 2014). Symptoms in solanaceous plants are similar to those associated with a reduction in nutrient supply and also to those caused by 'Ca. Phytoplasma spp.' and include: stunting, chlorosis and purpling of the foliage, upward rolling of the leaves, enlarged nodes, axillary branches or aerial tubers and production of poor quality fruits (Munyaneza et al. 
2007a, 2007b; Liefting et al. 2009a; Secor et al. 2009; Crosslin et al. 2010; Munyaneza et al. 2010a; Munyaneza 2012). CaLsol has also been associated with vegetative disorders in species of the family Apiaceae, including carrots (Daucus carota), celery (Apium graveolens) and parsnip (Pastinaca sativa) (EPPO 2013; Teresani et al. 2014; Alfaro-Fernández et al. 2011). In carrots, it has been reported that CaLsol symptoms also resemble those caused by a leafhopper-transmitted 'Ca. Phytoplasma spp.' and S. citri (Font et al. 1999; Lee et al. 2003; Duduk et al. 2007, 2008; Cebrián et al. 2010; Abed et al. 2011; Munyaneza et al. 2011).

Five haplotypes of CaLsol have been described (A, B, C, D, and E) (Nelson et al. 2011, 2012; Teresani et al. 2014). Haplotypes A and B are associated with diseases of potatoes and other solanaceous crops (haplotypes A and B in America and only haplotype A in New Zealand), and are transmitted by the psyllid Bactericera cockerelli. In Europe, haplotypes C, D and $\mathrm{E}$ are associated with carrot, celery and parsnip disorders (Nelson et al. 2012; Teresani et al. 2014). Haplotype C has been found in Finland and is transmitted by the psyllid Trioza apicalis (Munyaneza et al. 2014; Haapalainen et al. 2016), whereas haplotypes D and E have been found in Spain, France and Morocco (Teresani et al. 2014; Loiseau et al. 2014; Tahzima et al. 2014), and the main vector seems to be B. trigonica, at least in Spain (Teresani et al. 2015). Given that the symptoms observed in Tunisian carrots resembled those associated with CaLsol, a set of analyses on plants as well as on local seeds for CaLsol detection, was carried out. In addition, since 'Ca. Phytoplasma spp.' and Spiroplasma citri have also been reported affecting carrot with similar symptoms (Alfaro-Fernández et al. 2012), the detection of these two pathogens was also included.

\section{Materials and methods}

Plant extract preparation Inspections and samplings were carried out in carrot fields from 2014 to 2016 at Kairouan (Tunisia) (Fig. 1). General stunting, yellowing, purpling (Fig. 2a) and leaf curling (Fig. 2b), as well as shoot proliferation and hairy secondary roots (Fig. 2c) were frequently observed. A representative selection of symptomatic plants was collected. Mature leaf fragments were preserved in cryotubes with liquid nitrogen, and were sent in dry ice to the Bacteriology Laboratory of IVIA (Spain), where the samples were stored at $-20{ }^{\circ} \mathrm{C}$ before analysis.

Plant material (1 g/plant) was ground in plastic bags (Bioreba, Switzerland) in 1:5 to $10 \mathrm{ml}$ (w:v) of extraction buffer with phosphate-buffered saline (PBS) $\left(\mathrm{NaCl}, 8 \mathrm{~g} \mathrm{l}^{-1}\right.$; $\mathrm{NaH}_{2}-\mathrm{PO}_{4} .2 \mathrm{H}_{2} \mathrm{O}, 0.4 \mathrm{~g} \mathrm{l}^{-1} ; \mathrm{Na}_{2} \mathrm{HPO}_{4} .12 \mathrm{H}_{2} \mathrm{O}, 2.7 \mathrm{~g} \mathrm{l}^{-1}$; pH 7.2) using a Homex 6 homogenizer (Bioreba, Switzerland). Then, $1 \mathrm{ml}$ of each leaf extract was stored at $-80{ }^{\circ} \mathrm{C}$ until use.
Seed extract preparation Seed samples were prepared and analysed according to Bertolini et al. (2014b): $1 \mathrm{~g}$ (approximately 450 seeds) per lot was washed by shaking for $30 \mathrm{~min}$ in a tube containing $50 \mathrm{ml}$ washing buffer (distilled water with $0.5 \%$ Triton $\mathrm{X}-100)$. Then, washed seeds were placed into plastic bags with $10 \mathrm{ml}$ extraction buffer plus $0.2 \%$ sodium diethyl dithiocarbamate and 2\% PVP-10. The seeds were slightly crushed with a hammer, and $1 \mathrm{ml}$ of the extract from each seed lot was stored at $-80^{\circ} \mathrm{C}$ until use. Three seed lots of a local cultivar from the area of Rakada were analysed in 2015 and from Zaafrana in 2016.

Direct sample preparation without DNA purification (spot procedure) Freshly prepared extracts were immobilized on membranes (pieces of Whatman 3 MM filter paperHealthcare, Europe) on which $5 \mu \mathrm{l}$ of crude extract were loaded. Then, $100 \mu$ l of distilled water were added to each membrane in an Eppendorf tube and vortexed to extract the target DNA (Bertolini et al. 2014a; Teresani et al. 2014). The Eppendorf tubes were placed on ice and $3 \mu \mathrm{l}$ of the extract was used as a template for real-time PCR assays. For further assays, the membranes were removed before storing the tubes at $-20{ }^{\circ} \mathrm{C}$.

DNA purification Total DNA was purified from $200 \mu \mathrm{l}$ of crude plant or seed extract and $100 \mu \mathrm{l}$ from the spot procedure, using the cetyltrimethyl ammonium bromide (CTAB) protocol (Murray and Thompson 1980). Purified DNA was stored at $-20{ }^{\circ} \mathrm{C}$ until use.

Psyllid extract preparation Psyllids were captured from symptomatic plants using an entomological mouth aspirator. The putative individuals of $B$. trigonica and $B$. nigricornis were preserved in $70 \%$ ethanol. Psyllids were identified based on the male genitalia, according to Burckhardt and Freuler (2000). They were then squashed on Whatman 3 MM filter paper (HealthCare, Europe) with the rounded end of an Eppendorf tube according to Teresani et al. (2015). The membranes were carefully cut and inserted into Eppendorf tubes, distilled water $(100 \mu \mathrm{l}$ per tube) was added, the tubes vortexed, and the membranes removed before storing the tubes at $-20^{\circ} \mathrm{C}$, until used for amplification.

Real-time PCR CaLsol real-time PCR assays were performed according to Li et al. $(2006,2009)$ using a Light Cycler 480 (Roche, Switzerland). The reaction mix consisted of $1 \mathrm{X}$ Quantimix (Biotools, Spain), $0.24 \mu \mathrm{M}$ of each primer, $0.12 \mu \mathrm{M}$ of TaqMan probe and $3 \mu \mathrm{l}$ of the template (purified DNA or direct extraction from the spot) in a final volume of $12 \mu \mathrm{l}$. The real-time PCR amplification protocol included the following steps: $95^{\circ} \mathrm{C}$ for $20 \mathrm{~s}$ followed by 45 cycles of $95^{\circ} \mathrm{C}$ for $1 \mathrm{~s}$ and $58^{\circ} \mathrm{C}$ for $40 \mathrm{~s}$. Primers and probe sequences were, respectively: LsoF, 5'-GTCGAGCGCTTATTTTTAAT 




Fig. 1 Geographic location in Tunisia of the carrots fields sampled between years 2014 and 2016

AGGA-3'; HLBr, 5'-GCGTTATCCCGTAGAAAAAGG TAG-3'; and HLBp, 5'FAM-AGACGGGTGAGTAA CGCG-3'BHQ. The positive results (Ct values $\leq 40$ and exponential curve) and the negatives were also checked by the real-time PCR protocol of Teresani et al. (2014). In this case, the reaction mix consisted of $1 \mathrm{X}$ Quantmix (Biotools, Spain), $0.5 \mu \mathrm{M}$ of each primer, $0.16 \mu \mathrm{M}$ TaqMan probe and $3 \mu \mathrm{l}$ of the template. The amplification protocol consisted of $95{ }^{\circ} \mathrm{C}$ for $10 \mathrm{~min}$ followed by 45 cycles of $95{ }^{\circ} \mathrm{C}$ for $15 \mathrm{~s}$ and $60{ }^{\circ} \mathrm{C}$ for $1 \mathrm{~min}$. Primers and probe sequences were the following: CaLsppF, 5'-GCAGGCCTAACACATGCAAGT-3'); CaLsppR, 5'-GCACACGTTTCCATGCGTTAT-3'; and the specific TaqMan probe CaLsolP, 5' FAM-AGCGCTTA TTTTTAATAGGAGCGGCAGACG-3’ TAMRA (Teresani et al. 2014). Alternatively, a CaLsol/100 complete PCR kit (Plant Print Diagnostics, Spain) based on this last real-time PCR was used following the manufacturer's instructions.

Purified DNA and spots of crude extracts prepared from stored symptomatic carrot plants positive for CaLsol were used as positive controls in each PCR assay. DNase-free distilled water and spotted pieces of membrane with a crude healthy carrot extract were used as negative controls. All the samples were analysed at least three times. 
Fig. 2 Yellowing symptoms on carrots collected from 2014 to 2016 at Kairouan (Tunisia). a yellowing and purpling on young and mature carrot leaves. b curling on new carrot leaves. c stunting of carrot shoots and abundance of stems and secondary roots
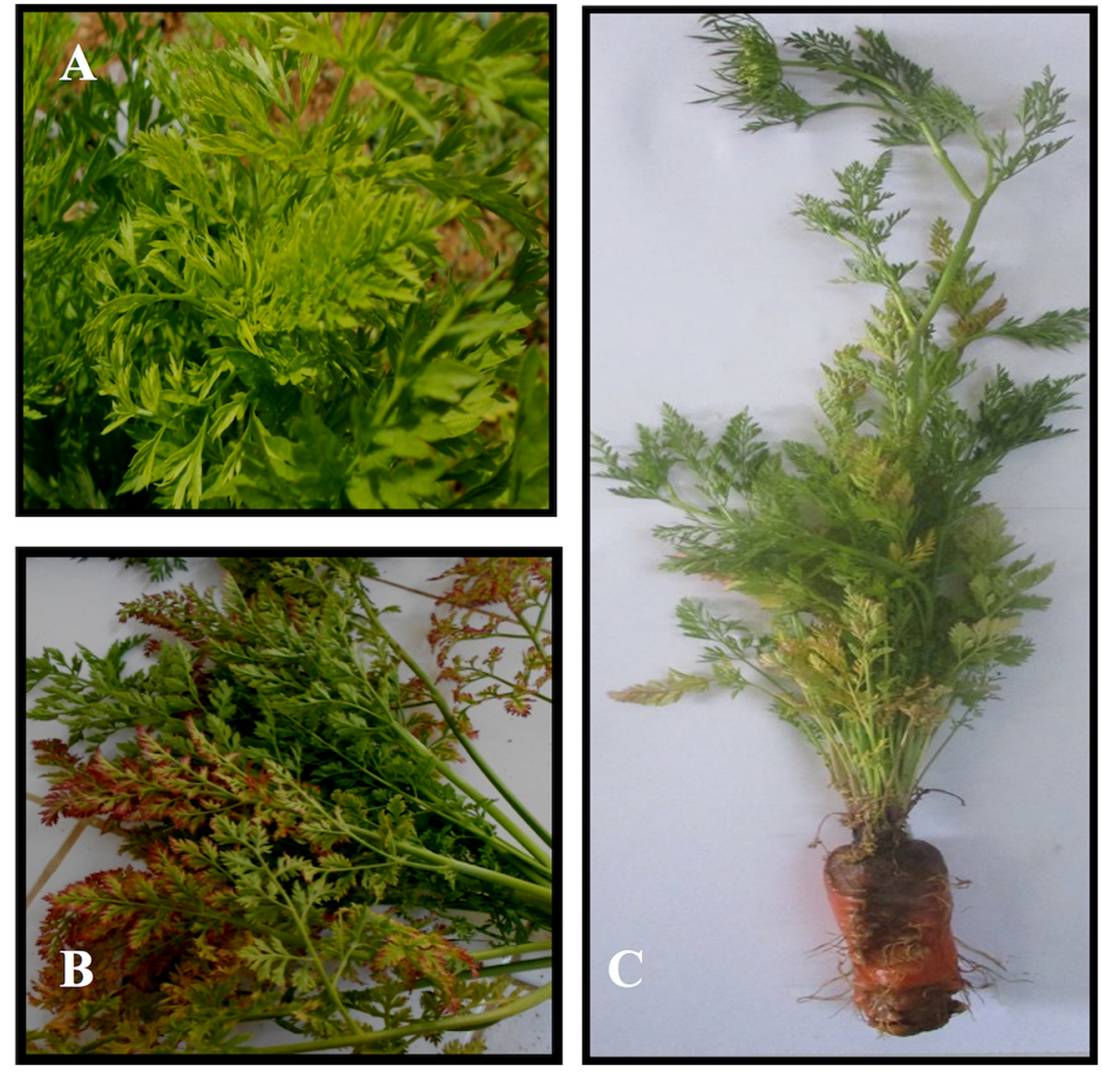

'Ca. Phytoplasma spp.' presence was screened by real-time PCR according to Hren et al. (2007) using the universal primers UniRNA. The reaction mix consisted of $1 \mathrm{X}$ PathID $^{\text {TM }}$ qPCR (Ambion, USA), $1 \mu \mathrm{M}$ of each primer, $0.5 \mu \mathrm{M}$ of TaqMan MGB probe and $3 \mu \mathrm{l}$ of template. The amplification protocol consisted of $95{ }^{\circ} \mathrm{C}$ for $10 \mathrm{~min}$, followed by 45 cycles of $95{ }^{\circ} \mathrm{C}$ for $15 \mathrm{~s}$, and $64^{\circ} \mathrm{C}$ for $1 \mathrm{~min}$. Primer and probe sequences were: UniRNA-F, 5'-AAATATAG TGGAGGTTATCAGGGATACAG-3'; UniRNA-R, 5'AACCTAACATCTCACGACACGAACT-3' and the specific TaqMan MGB probe, 5'FAM-ACGACAACCATGCACCA3. MGB.

S. citri presence was also screened by real-time PCR, following the protocol of Alfaro-Fernández et al. (2017). The reaction mix consisted of $1 \mathrm{X}$ Path-ID ${ }^{\mathrm{TM}} \mathrm{qPCR}$ (Ambion, USA) $10 \mu \mathrm{M}$ of each primer, $0.5 \mu \mathrm{M}$ of TaqMan MGB probe and $3 \mu \mathrm{l}$ of template. The amplification protocol consisted of $95^{\circ} \mathrm{C}$ for $10 \mathrm{~min}$ followed by 45 cycles of $95^{\circ} \mathrm{C}$ for $15 \mathrm{~s}$ and $58^{\circ} \mathrm{C}$ for $1 \mathrm{~min}$. Primers and probe sequences were: SCPA-F, 5'-GAAATACTGATAATGGCAAACAGTTTG-3'; SCPAR, 5'-ACTAGCACTATACCCACGGATATTGT-3'; and the specific TaqMan MGB probe SCPA-P, 5' FAMATATGAGCGAAAGCAAAT $-3^{\prime}$ MGB. The protocols of real-time PCR described for detection of $S$. citri and ' $\mathrm{Ca}$. Phytoplasma spp.' were used on a StepOne Plus thermal cycler (Applied Biosystems, USA) and the analyses were repeated at least twice.
Determination of bacterial viability To quantify the live CaLsol bacteria, $0.2 \mathrm{ml}$ aliquots from seed samples were treated with propidium monoazide (PMA) at a final concentration of $100 \mu \mathrm{M}$. PMA selectively enters dead cells and, upon photo-activation, it intercalates and binds covalently to DNA strongly inhibiting its PCR amplification. Tubes were incubated at $30^{\circ} \mathrm{C}$ in the dark for $10 \mathrm{~min}$, with occasional inversion to allow the dye to intercalate with the DNA. After incubation, tubes were vortexed for $5 \mathrm{~s}$ and exposed to $100 \%$ light intensity for $15 \mathrm{~min}$ in a PhAST Blue apparatus (GenIUL, Spain). Subsequently, DNA was extracted from both PMA-treated and untreated samples using the CTAB method and samples were analysed by real-time PCR. Cells number were estimated using cycle threshold $(\mathrm{Ct})$ values from these assays to estimate cells number from a modified standard curve according to Bertolini et al. (2014b), including corrections considering that each bacterial cell contains three copies of the 16S rRNA gene according to Nelson et al. (2015).

Haplotype characterisation and phylogenetic analyses To determine the genetic diversity of Tunisian CaLsol, haplotypes were characterized based on single nucleotide polymorphisms (SNPs) typing of partial regions of the genes 16S rDNA (16S rRNA), 16S-23S rDNA intergenic spacer region (IGS), and $r p l J$ and $r p l L$ ribosomal protein genes (50S subunit) by phylogenetic analysis. The amplification of the 16S rRNA was performed using the forward primer designed by Li et al. 
(2009), from a region of the $16 \mathrm{~S}$ rRNA gene that is unique to CaLsol, in combination with the universal Liberibacter reverse primer of Jagoueix et al. (1996). The IGS was amplified using the primers of Ravindran et al. (2011). Finally, the 50S ribosomal protein genes $r p l J$ and $r p l L$ were amplified with the new primers: CaLsol 50S-F (5'-CGAGACCATTGAAC ACAACG-3') and CaLsol 50S-R (5'- TGGAGGAG GAGTGAGAAT-3'). These primers were designed in this study from the complete genome of CaLsol strain R1 (GenBank accession No. CP002371) available in GenBank database with SnapGene software (GSL Biotech, USA). The rplJ-rplL locus was amplified by placing the reaction mixture conditions (final concentration of $1 \mathrm{X}$ Taq DNA polymerase buffer containing $2 \mathrm{mM} \mathrm{MgCl}$, $400 \mathrm{nM}$ of each primer, $400 \mu \mathrm{M}$ dNTPs, $1 \mathrm{U}$ Taq DNA polymerase and $2 \mu \mathrm{l}$ DNA template) in a thermocycler GeneAmp PCR System 9600 (Applied Biosystem/ Perkin Elmer, USA) at $94{ }^{\circ} \mathrm{C}$ for $5 \mathrm{~min}$, followed by 40 cycles at $94{ }^{\circ} \mathrm{C}$ for $30 \mathrm{~s}, 56^{\circ} \mathrm{C}$ for $30 \mathrm{~s}$ and $72{ }^{\circ} \mathrm{C}$ for $1 \mathrm{~min}$. Final elongation was $10 \mathrm{~min}$ at $72{ }^{\circ} \mathrm{C}$, giving an amplicon of $946 \mathrm{bp}$. The results were compared with those obtained following Munyaneza et al. (2009). Purification of the amplified fragment from the PCR products was performed following the instructions provided by the Kit Invisorb Spin DNA extraction (Invisorb, Germany), and then quality tested with a NanoDrop spectrophotometer (Thermo Scientific, USA). The sequencing was performed with two readings (forward and reverse) by the Sequencing Service of the Institute of Molecular and Cell Biology of Plants (IBMCP) (Valencia-Spain) and the quality and detection of secondary peaks in chromatograms were determined with the package SangeranalyseR, tools for Sanger sequencing data (Hill et al. 2014) in R software ( $\mathrm{R}$ Core Team 2016).

All sequences were subjected to molecular phylogenetic analysis performed with MEGA 6 software (Tamura et al. 2013) by Maximum Likelihood Method performed on 1000 replicates.

\section{Results}

Analyses of carrot plants The results of CaLsol detection in the carrot samples analysed in 2015 and 2016 are shown in Table 1. The data show the average Cts from three repetitions of each sample. Positive samples using the Li et al. (2009) protocol were detected both in 2015 and 2016 in the two surveyed and sampled areas. In 2015, four positive samples out of 43 were found, and in 2016 ten samples out of 50. Most of the samples were analysed directly from spots or after CTAB extraction. In some cases, a 1:10 and 1:100 dilution of the spots was evaluated in order to discount the presence of polymerase inhibitors as shown in the Table 1. Many negative and positive samples were also tested by the Teresani et al. (2014) assay, or with the Plant Print kit with the same results, with the exception of eight clear positive samples by Li et al. (2009) that were only detected by Teresani et al. (2014) in late cycles.

All analysed carrot plants were negative for ' $\mathrm{Ca}$. Phytoplasma spp.' using universal primers, and also for S. citri using specific primers (Table 1).

Analysis of seeds Three lots of seed samples analysed (SE in Table 1) in 2015 were negative for CaLsol, while the three lots of cv. Arbi Zaafrana analysed in 2016 were highly contaminated. Moreover, the viability of CaLsol cells in seeds was very high and ranged from $36 \%$ (SE.5) to $65 \%$ (SE.4), with an average value of $46 \%$ (Table 2, Fig. 3 ).

Analysis of psyllids A selection of 49 squashed and immobilized adults of B. trigonica (samples $\mathrm{T}$ in Table 1) and eight adults of $B$. nigricornis (samples $\mathrm{N}$ in Table 1) were analysed directly from spots for CaLsol, but all of them were negative.

Haplotype characterisation and phylogenetic analyses The haplotype was determined for 14 samples that were positive in real time PCR for CaLsol, using the three primer sets to ribosomal regions described previously (16S rRNA, IGS, and $r p l J$ and $r p l L$ ribosomal protein genes), but in many cases amplification of all three regions was not achieved. Four samples (three carrot seeds SE4, 5 and 6 and the plant sample Z3), where amplification of all three regions was obtained, were selected for further investigation. Interestingly, the new primers designed for amplification and sequencing of rplJ and $r p l L$ ribosomal protein genes fragments gave stronger positive amplicons than the primers described by Munyaneza et al. (2009). As an example, the amplification obtained with primers to both $r p l J$ and $r p l L$ ribosomal protein genes regions of infected carrot seeds are shown in Fig. 4.

Chromatograms from three carrot seed sequences, SE4, 5 and 6 showed that the three sequences were identical and were haplotype D. These were deposited in GenBank database: $16 \mathrm{~S}$ rRNA partial gene (Acc. number: KY468271); IGS (Acc. number: KY464018) and rplJ-rplL ribosomal protein genes (Acc. number: KY753132).

For the carrot plant (Z3) the sequencing chromatograms obtained for the reverse and complementary strands, in the three ribosomal regions, showed two different signals in key SNPs used for haplotyping. These differences corresponded to haplotype D and haplotype E, indicating the possible presence of both haplotypes in the same sample (Fig. 5). Sequences deposited in GenBank database were: 16S rRNA partial gene (Acc. numbers: KY295907 and KY295908, respectively); IGS (Acc. numbers: KY296296 and KY296295, respectively) and rplJ-rplL ribosomal protein genes (Acc. numbers: KY777461 and KY777462, respectively). The phylogenetic relationships of these sequences with the five characterised 


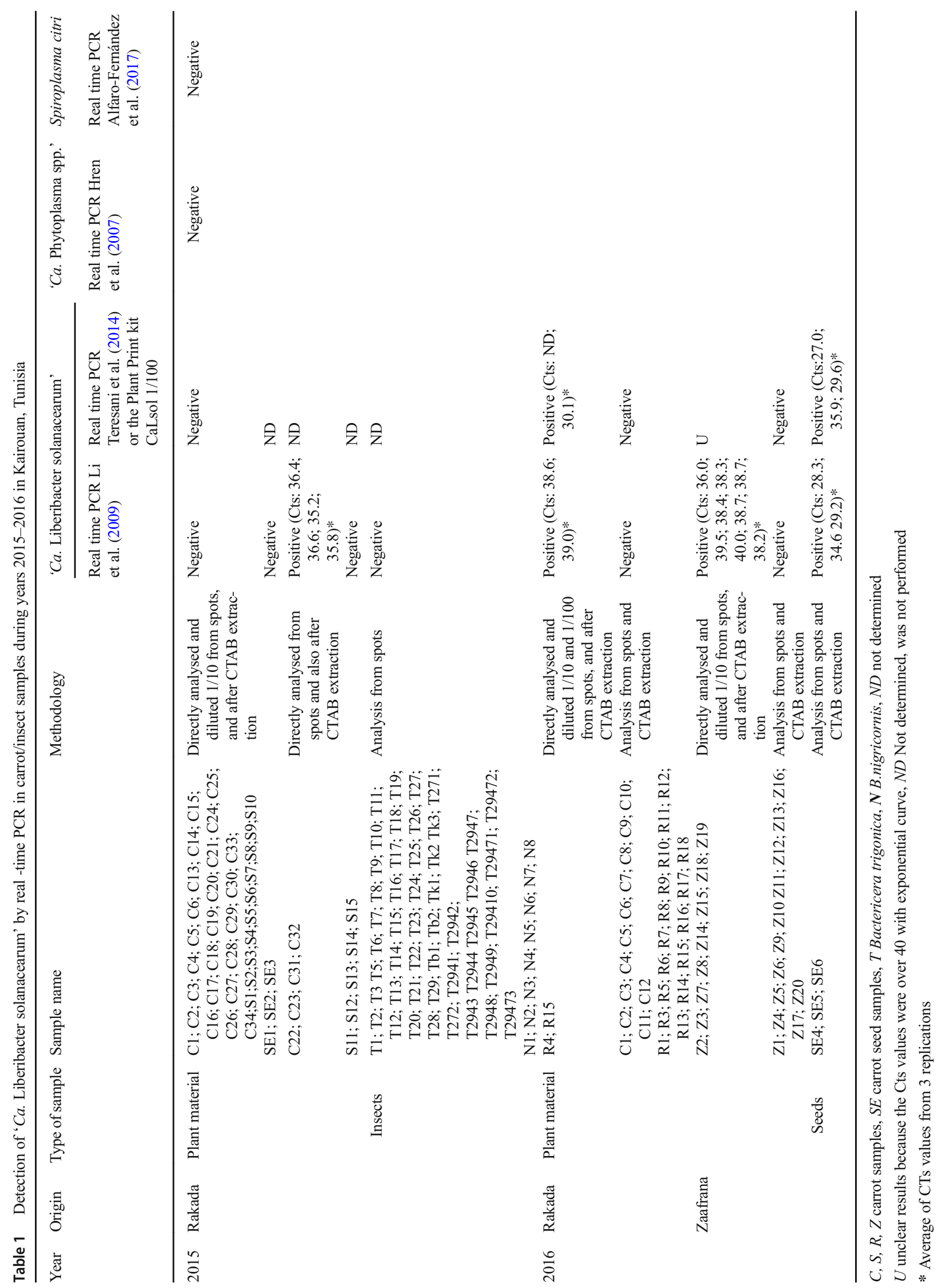


Table 2 Viability of ' $\mathrm{Ca}$. Liberibacter solanacearum' cells present in carrot seeds as determined by PMA methodology (Bertolini et al. 2014b)

\begin{tabular}{|c|c|c|c|c|c|}
\hline Seed lot & Addition of PMA & Average $\mathrm{Ct}$ values* & Cell number & Viable cells $(\%)$ & Non viable cells $(\%)$ \\
\hline SE.4 & $\begin{array}{l}\text { No } \\
\text { Yes }\end{array}$ & $\begin{array}{l}29.3 \\
(\mathrm{SE}=0,20) \\
29.9 \\
(\mathrm{SE}=0,24)\end{array}$ & $\begin{array}{l}3.37 \times 10^{2} \\
2.21 \times 10^{2}\end{array}$ & 65.38 & 34.62 \\
\hline SE.5 & $\begin{array}{l}\text { No } \\
\text { Yes }\end{array}$ & $\begin{array}{l}29.3 \\
(\mathrm{SE}=0,24) \\
30.8 \\
(\mathrm{SE}=0,11)\end{array}$ & $\begin{array}{l}3.30 \times 10^{2} \\
1.20 \times 10^{2}\end{array}$ & 36.37 & 63.63 \\
\hline SE.6 & $\begin{array}{l}\text { No } \\
\text { Yes }\end{array}$ & $\begin{array}{l}30.6 \\
(\mathrm{SE}=0,36) \\
31.8 \\
(\mathrm{SE}=0,52)\end{array}$ & $\begin{array}{l}1.40 \times 10^{2} \\
5.81 \times 10^{1}\end{array}$ & 41.03 & 58.97 \\
\hline Average value & & & & 46.04 & 53.96 \\
\hline
\end{tabular}

*Average of CTs values from 5 replications. SE: Standard error

haplotypes are shown in Fig. 6 and confirm their status as haplotypes D and E.

\section{Discussion}

The emerging bacterium CaLsol is associated with socioeconomically important diseases in many crops (Munyaneza 2012; Haapalainen 2014). Its presence has been reported in several species of Solanaceae (Liefting et al. 2009b) and in plants of Apiaceae (Munyaneza et al. 2012a, b), being associated with vegetative disorders. In carrots, the bacterium has been detected in European countries such as Spain (AlfaroFernández et al. 2012), Finland (Haapalainen 2014), Sweden (Munyaneza et al. 2012a), and France (Loiseau et al. 2014), and was also reported from Morocco (Tahzima et al. 2014).

CaLsol-like symptoms were observed through 20142016 in carrots cultivated in different areas of Kairouan in Tunisia and the presence of CaLsol was confirmed in symptomatic carrot plants by real-time PCR. Moreover, the positive results obtained using the Li et al. (2009) protocol

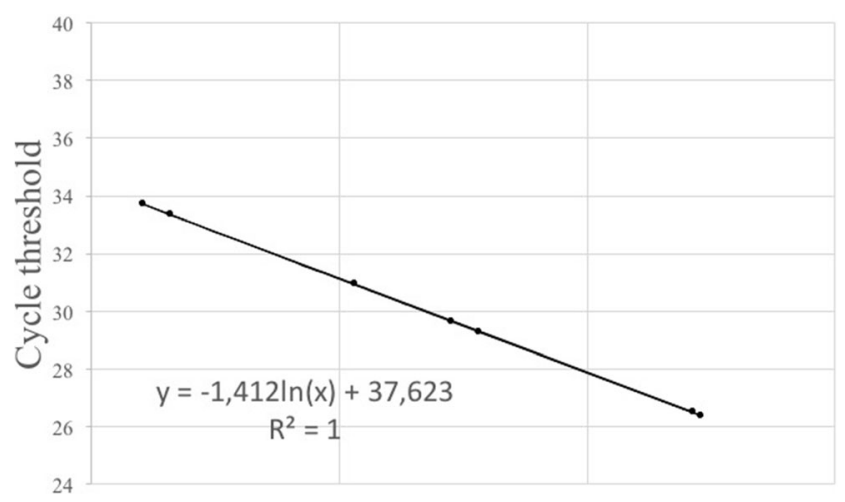

Log of cell number

Fig. 3 Figure 3. Standard curve including corrections according to Nelson et al. (2015): $y=-1,412 \ln (x)+37,623 ; R^{2}=1$ were confirmed using the Teresani et al. (2014) assay or the Plant Print Diagnostics real-time kit, increasing the reliability of the diagnosis. These are protocols recommended by FAO-IPPC (2017).

However, CaLsol was not detected in all the symptomatic plants tested. This may be due to a number of factors: (i) high temperature, because temperatures close to $30{ }^{\circ} \mathrm{C}$ or higher may affect the prevalence of the high temperature sensitive CaLsol (Munyaneza et al. 2012c). At the time of sampling temperatures were above $30^{\circ} \mathrm{C}$, although temperatures during the growing season varied between 24 and $33{ }^{\circ} \mathrm{C}$ (www. meteo.tn/, dates from 2016); (ii) an uneven CaLsol distribution in the phloem, that could lead to samples testing negative; (iii) variable bacterial titer that may be below the level of detection according to the season and the plant organ infected (data not shown); (iv) time delay between samples collection and their analysis and/or the use of frozen samples, leading to CaLsol DNA degradation. As the disease in carrots has only recently been reported, the influence of these factors on CaLsol levels in plant tissues is not well understood. Furthermore, the presence of inhibitory compounds in plant tissues could also hamper detection, as they are a major impediment to successful DNA amplification. Consequently, 1: 10 and 1:100 extract dilutions were tested to minimize the action of possible polymerase inhibitors but no improvement in amplification was found. In addition, in order to improve the efficiency of detection, different combinations of extraction procedures (spot PCR and modified CTAB extraction) were evaluated to optimize DNA amplification but with no improvement.

Some European laboratories have found difficulties in amplifying some regions used for haplotyping which may be due to the low concentration of the bacterium in the analysed samples. For this reason, a new PCR protocol for amplifying a fragment of the gene rplJ-rpl was designed because our PCR products were weak with protocol described in Munyaneza et al. (2009). 


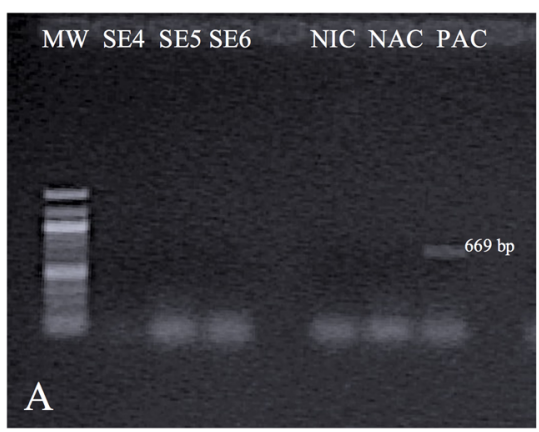

Fig. 4 Agarose gel electrophoresis of PCR amplification from DNA extracts of carrot seeds (SE4, SE5 and SE6) from Kairouan (Tunisia) with two primer pairs. a CL514F/R according to Munyaneza et al. (2009); (b) CaLsol 50SF/R designed in this study. Lane NIC depicts negative

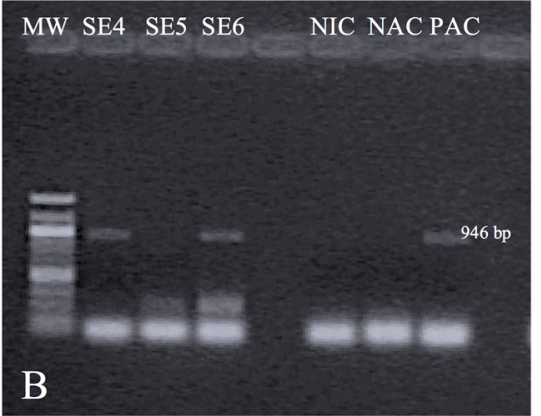

isolation control. Lane NAC depicts negative amplification control. Lane PAC depicts positive amplification control corresponding to a potato sample infected with CaLsol. MW depicts 100 bp DNA ladder
A



Region of gene $r p / J$ - rp/L positions marked: 700; 722 y 749

B

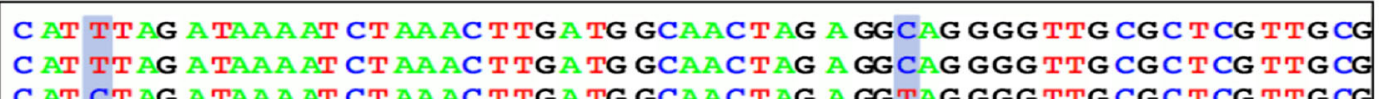

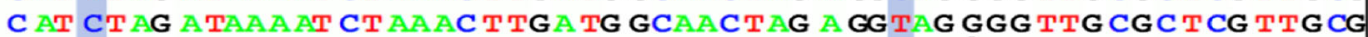

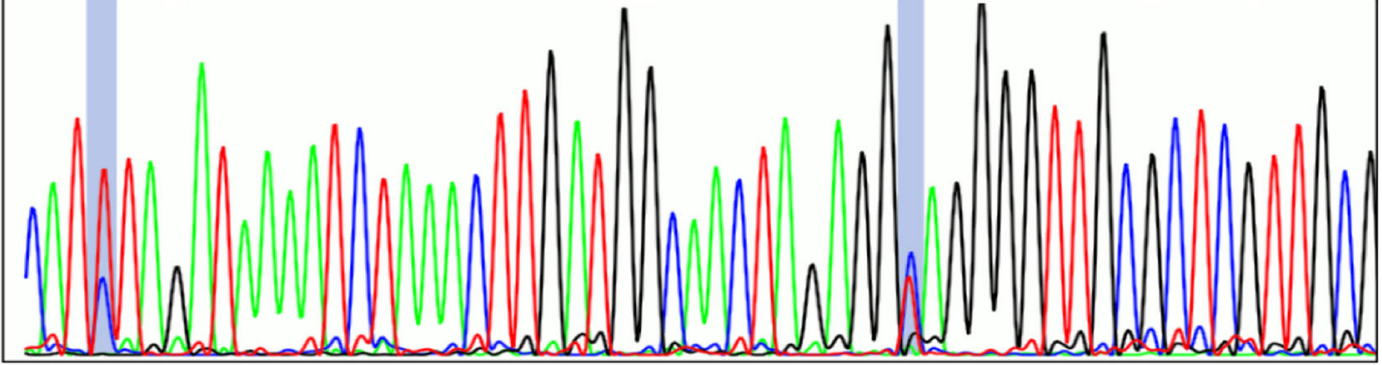

Region of gene 16S rRNA positions marked: 1073 y 1039

$\mathrm{C}$

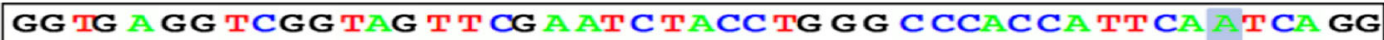

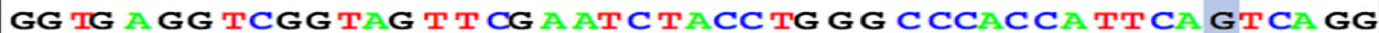





Region of gene 16S-23S rRNA IGS positions marked: 1620

Fig. 5 Chromatogram of sequences of sample Z3 of partial regions of three genes: (a) ribosomal protein $r p l J$ and $r p l L$ (50S rRNA); (b) 16S rDNA (16S rRNA gene) and (c) IGS where the key SNPs found in the primary and secondary sequences are marked with grey bars
EU834131

Primary sequence $\mathrm{Z3}$

Secondary sequence $Z 3$

EU812559

Primary sequence 73

Secondary sequence $Z 3$

EU812559

Secondary sequence $Z 3$
Primary sequence $Z 3$ 
Fig. 6 Phylogenetic tree using the Maximum Likelihood method based on the 3-parameter model using MEGA6. Bootstrap test of phylogeny was performed with 1000 replicates. The analysis involved nucleotide sequences from database GenBank of (a) the $50 \mathrm{~S}$ ribosomal protein genes $r p l J$ and $r p l L$ and (b) $16 \mathrm{~S}$ rRNA partial genes of the haplotypes of CaLsol. Sequence of samples analysed in this study are marked with a large black dot
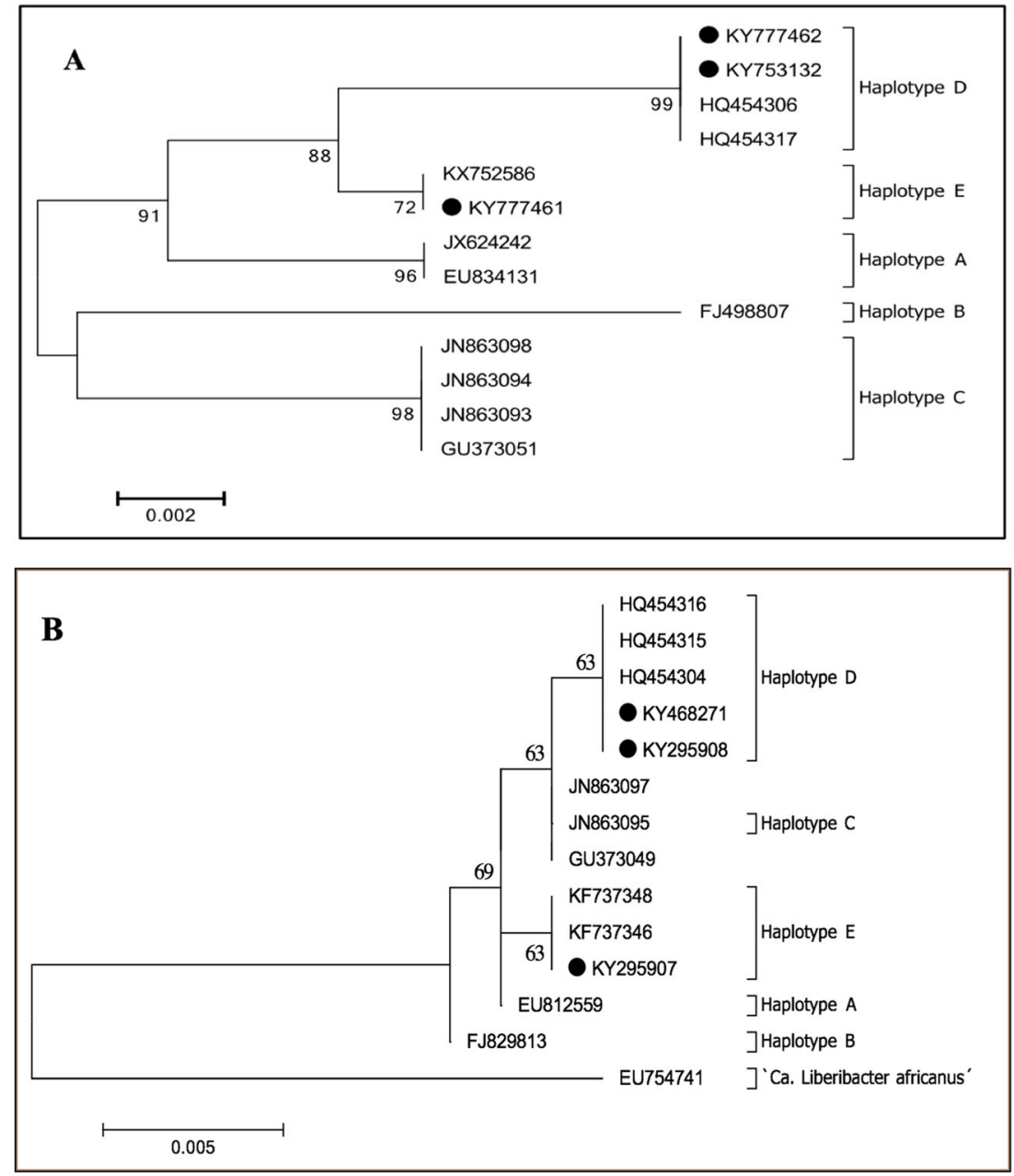

Analysis of CaLsol positives samples showed that only haplotype D was present in carrot seeds but haplotypes D and $\mathrm{E}$ were present in one carrot plant (Fig. 6). Due to the limited amount of DNA of this sample (Z3), we could not clone the amplicons to confirm the presence of both fragments of each haplotype. However, co-infection has already been described for haplotypes A and B in potato and potatopsyllid samples (Wen et al. 2013), but this is the first report of co-infection of haplotypes D and E in carrot. Since haplotype $\mathrm{E}$ is the most frequent haplotype found in carrot in Southern European countries (Alfaro-Fernández et al. 2012) and some of the cultivars found infected, such as cv. Maestro, are the same as those found infected in Europe, and were provided by the same companies, this haplotype may have been introduced through contaminated seeds (Bertolini et al. 2014b).

Using real-time PCR a high level of CaLsol was detected in 2016 in three carrot seed lots of the cv. Arbi Zaafrana, with a high number of quantified viable cells found after PMA treatment, higher than $35 \%$ in all cases and reaching $65 \%$ in one of the lots. These percentages are much higher than those reported by Bertolini et al. (2014b) and may be due to the lack of seed treatments performed by Tunisian growers on locally produced seed, in contrast to the treated commercially available seeds. The locally produced seeds had not been checked for CaLsol before sowing but, according to information from the growers, they were probably collected from infected mother plants.

Viable CaLsol cells in seeds were shown to be responsible for infection of carrot seedlings germinated from contaminated seeds (Bertolini et al. 2014b). However, transmission of this pathogen by carrot seeds seems to be not a major transmission pathway, in comparison to vector transmission, probably because other unknown parameters are influential in the development of the disease (Loiseau et al. 2017). If the primary inoculum of haplotype D in Tunisia is CaLsol contaminated seed, treatment of carrot seeds would be a key mitigation strategy for preventing the disease (Bertolini et al. 2014b; Ilardi et al. 2016), for example by hot water treatment (Australian Government Department of Agriculture and Water Resources 2017).

In Kairouan, it has only been possible to test a relatively low number of identified B. trigonica and B. nigricornis individuals for CaLsol by direct analysis of squashed 
psyllids. As these insects were negative for CaLsol,, more individuals of these and other species should be collected and analysed to determine their possible role in transmission, because different psyllid species have been reported as vectors in several European countries (Munyaneza et al. 2010b; Teresani et al. 2015).

The negative results for the detection of ' $\mathrm{Ca}$. Phytoplasma spp.' and $S$. citri suggests that CaLsol is the only bacterial agent associated with the symptoms observed in carrots in Kairouan, and with the commercial losses due to the poor quality of these plants. The information from the current study will help carrot growers to develop preventive and pest management strategies, such as analysis of seed lots, elimination of symptomatic plants, and analysis and control of potential vectors to reduce the incidence and spread of this emerging bacterium to other apiaceous or solanaceous hosts, and to other Tunisian regions. The recent discovery of this bacterium in Morocco (Tahzima et al. 2014), together with our results suggests that this emerging pathogen is spreading in North Africa and other Mediterranean countries. Thus, the National Plant Protection Organisations should be alerted to the threat that CaLsol poses to solanaceous and apiaceous cultivated plant species.

Acknowledgements This work was supported by an IVIA grant (project 51407) and by the European Union's Horizon 2020 research and innovation programme (grant agreement No. 635646) project POnTE (Pests Organisms Threathening Europe). F.E. Morán is the recipient of a fellowship co-funded by IVIA and European Social Fund. We also thank, Javier Peñalver, Clara Morente and Adela Monterde for technical support; Carlos Marroquín for support in psyllids identification; and Jaime Cubero and José Francisco Català for bioinformatics support. The authors especially thank l'Union Tunisienne de l'Agriculture et de la Pêche (UTAP), Kairouan, Tunisia, for facilitating the field work in the governorate of Kairouan, and the critical reading and useful suggestions of the anonymous referees to improve the quality of the manuscript.

Open Access This article is distributed under the terms of the Creative Commons Attribution 4.0 International License (http:// creativecommons.org/licenses/by/4.0/), which permits unrestricted use, distribution, and reproduction in any medium, provided you give appropriate credit to the original author(s) and the source, provide a link to the Creative Commons license, and indicate if changes were made.

\section{References}

Abed G, Maslenin L, Weintraub PG, Mawassi M (2011) Phytoplasma and Spiroplasma diseases in open-field crops in Israel. Bull Insectol 64:53-54

Alfaro-Fernández A, Cebrián MC, Villaescusa FJ, Font MI (2011) Detection and identification of aster yellows and stolbur phytoplasmas in various crops in Spain. Bull Insectol 64(Supplement):S63-S64

Alfaro-Fernández A, Cebrián MC, Villaescusa FJ, Hermoso de Mendoza FJ, Ferrándiz JC, Sanjuán S, Font MI (2012) First report of 'Candidatus Liberibacter solanacearum' in carrot in mainland Spain. Plant Dis 96:582
Alfaro-Fernández A, Ibañez I, Bertolini E, Hernández-Llopis D, Cambra M, Font MI (2017) Transmission of Spiroplasma citri in carrot seeds and development of a real-time PCR for its detection. J Plant Pathol 99:371-379

Australian Government Department of Agriculture and Water Resources, 2017. Final pest risk analysis for 'Candidatus Liberibacter solanacearum' associated with apiaceous crops. Department of Agriculture and Water Resources, Canberra, ACT, Australia,

Bertolini E, Felipe RTA, Sauer AV, Lopes SA, Arilla A, Vidal E, Mourão Filho FA, Nunes WMC, Bové JM, López MM, Cambra M (2014a) Tissue-print and squash real time polymerase chain reaction for direct detection of 'Candidatus Liberibacter' species in citrus plants and psyllid vectors. Plant Pathol 63:1149-1158

Bertolini E, Teresani GR, Loiseau M, Tanaka FAO, Barbé S, Martínez MC, Gentit P, López MM, Cambra M (2014b) Transmission of 'Candidatus Liberibacter solanacearum' in carrot seeds. Plant Pathol 64:276-285

Burckhardt D, Freuler J (2000) Jumping plant-lice (Hemiptera, Psylloidea) from sticky traps in carrot fields in Valais, Switzerland. Mitteilungen der Schweizerischen Entomologishchen Gesellschaft 73:191-209

Cebrián MC, Villaescusa FJ, Alfaro-Fernández A, Hermoso de Mendoza A, Córdoba-Sellés MC, Jorda C, Ferrándiz JC, Sanjuan S, Font MI (2010) First report of Spiroplasma citri in carrot in Europe. Plant Dis 94:1264

Crosslin JM, Munyaneza JE, Brown JK, Liefting LW (2010) Potato zebra chip disease: a phytopathological tale. Plant Health Progress. https://doi.org/10.1094/PHP-2010-0317-01-RV

Duduk B, Bulajić A, Duduk N, Calari A, Paltrinieri S, Krstić B, Bertaccini A (2007) Identification of phytoplasma belonging to aster yellows ribosmal group in vegetables in Serbia. Bull Insectol 60: 341-342

Duduk B, Perić P, Marčić D, Drobnjaković T, Picciau L, Alma A, Bertaccini A (2008) Phytoplasmas in carrots: disease and potential vectors in Serbia. Bull Insectol 61:327-331

EPPO (European and Mediterranean Plant Protection Organization) (2013) Data sheets on pests recommended for regulation. 'Candidatus Liberibacter solanacearum'. Bull OEPP/EPPO 43: 197-201

Fagen J, Leonard MT, McCullough CM, Triplett EW, Davis MJ (2014) Liberibacter crescens gen. nov sp., nov., first cultured member of the Liberibacter genus. Int J Syst Evol Bacteriol 64:2461-2466

FAO-IPPC (International Plant Protection Convention), 2017. Diagnostic protocols DP 21 'Candidatus Liberibacter solanacearum'. ISPM27. Annex 21

Font MI, Abad P, Albiñana M, Espino AI, Dally DRE, Jordá C (1999) Amarilleos y enrojecimientos en zanahoria: una enfermedad a diagnóstico. Boletín de Sanidad Vegetal de Plagas 25:405-415

Haapalainen M (2014) Biology and epidemics of 'Candidatus Liberibacter' species, psyllid-transmitted plant-pathogenic bacteria. Ann Appl Biol 165:172-198

Haapalainen M, Kivimäki P, Latvala S, Rastas M, Hannukkala A, Jauhiainen L, Lemmetty A, Pirhonen M, Virtanen A, Nissinen AI (2016) Carrot pathogen 'Candidatus Liberibacter solanacearum' haplotype $\mathrm{C}$ is frequent and widely occurring in several areas in the southern part of Finland. Plant Pathol 66:559-570

Hill JT, Demarest BD, Bisgrove BW, Yi-chu S, Smith H, Yost J (2014) Poly peak parser: Method and software for identification of unknown indels using Sanger sequencing of polymerase chain reaction products. Dev Dyn 243:1632-1636

Hren M, Boben J, Rotter A, Kralj P, Gruden K, Ravnikar M (2007) Realtime PCR detection systems for flavescence dorée and bois noir phytoplasmas in grapevine: comparison with conventional PCR detection and application in diagnostics. Plant Pathol 56:785-796 
Ilardi V, Di Nicola E, Tavazza M (2016) First report of 'Candidatus Liberibacter solanacearum' in commercial carrot seeds in Italy. J Plant Pathol 98:374

Jagoueix S, Bové JM, Garnier M (1996) PCR detection of the two 'Candidatus Liberibacter' species associated with greening disease of citrus. Mol Cell Probes 10:43-50

Lee IM, Martini M, Bottner KD, Dane RA, Black MC, Troxclair N (2003) Ecological implications from a molecular analysis of phytoplasmas involved in an aster yellows epidemic in various crops in Texas. Phytopathology 93:1368-1377

Li W, Hartung JS, Levy L (2006) Quantitative real-time PCR for detection and identification of 'Candidatus Liberibacter' species associated with citrus huanglongbing. J Microbiol Methods 66:104-115

Li W, Abad JA, French-Monar RD, Rascoe J, Wen A, Gudmestad NC, Secor GA, Lee IM, Duan Y, Levy L (2009) Multiplex real-time PCR for detection, identification and quantification of 'Candidatus Liberibacter solanacearum' in potato plants with zebra chip. J Microbiol Methods 78:59-65

Liefting LW, Sutherland PW, Ward LI, Paice KL, Weir BS, Clover GRG (2009a) A new 'Candidatus Liberibacter' species associated with diseases of solanaceous crops. Plant Dis 93:208-214

Liefting LW, Weir BS, Pennycook SR, Clover GRG (2009b) 'Candidatus Liberibacter solanacearum', a Liberibacter associated with plants in the family Solanaceae. Int J Syst Evol Microbiol 59:2274-2276

Lin H, Doddapaneni H, Munyaneza JE, Civerolo E, Sengoda VG, Buchman JL, Stenger DC (2009) Molecular characterization and phylogenetic analyses of 16S rRNA from a new species of 'Candidatus Liberibacter' associated with zebra chip disease of potato (Solanum tuberosum L.) and the potato psyllid (Bactericera cockerelli Sulc). J Plant Pathol 91:215-219

Loiseau M, Garnier S, Boirin V, Merieau M, Leguay A, Renaudin I, Renvoisé JP, Gentit P (2014) First report of 'Candidatus Liberibacter solanacearum' in carrot in France. Plant Dis 98:839

Loiseau M, Isabelle R, Pascaline C, Pierre-Marie L, Aurélie F, Pascal $G$ (2017) Lack of evidence of vertical transmission of 'Candidatus Liberibacter solanacearum' by carrot seeds suggests that seed is not a major transmission pathway. Plant Dis (in press) http://apsjournals.apsnet.org/doi/10.1094/PDIS-04-17-0531-RE

Munyaneza JE (2012) Zebra chip disease of potato: biology, epidemiology and management. Am J Potato Res 89:329-350

Munyaneza JE, Crosslin JM, Upton JE (2007a) Association of Bactericera cockerelli (Homoptera: Psyllidae) with "zebra chip", a new potato disease in southwestern United States and Mexico. J Econ Entomol 100:656-663

Munyaneza JE, Goolsby JA, Crosslin JM, Upton JE (2007b) Further evidence that zebra chip potato disease in the lower Rio Grande Valley of Texas is associated with Bactericera cockerelli. Subtrop Plant Sci 59:30-37

Munyaneza JE, Sengoda VG, Crosslin JM, Rosa-Lozano G, Sanchez A (2009) First report of 'Candidatus Liberibacter psyllarous' in potato tubers with Zebra chip disease in Mexico. Plant Dis 93:552

Munyaneza JE, Fisher TW, Sengoda VG, Garczynski SF (2010a) First report of 'Candidatus Liberibacter solanacearum' associated with psyllid-affected carrots in Europe. Plant Dis 94:639

Munyaneza JE, Fisher TW, Sengoda VG, Garczynski SF, Nissinen A, Lemmetty A (2010b) Association of "Candidatus Liberibacter solanacearum" with the psyllid Trioza apicalis (hemiptera: Triozidae) in Europe. J Econ Entomol 103:1060-1070

Munyaneza JE, Lemmetty A, Nissinen AI, Sengoda VG, Fisher TW (2011) Molecular detection of aster yellows phytoplasmas and
'Candidatus Liberibacter solanacearum' in carrots affected by the psyllid Trioza apicalis (Hemiptera: Triozidae) in Finland. J Plant Pathol 93:697-700

Munyaneza JE, Sengoda VG, Stegmark R, Arvidsson AK, Anderbrant O, Yuvaraj JK, Rämert B, Nissinen A (2012a) First report of 'Candidatus Liberibacter solanacearum' associated with psyllidaffected carrots in Sweden. Plant Dis 96:453

Munyaneza JE, Sengoda VG, Sundheim VGL, Meadow R (2012b) First report of 'Candidatus Liberibacter solanacearum' associated with psyllid-affected carrots in Norway. Plant Dis 96:454

Munyaneza JE, Sengoda VG, Buchman JL, Fisher TW (2012c) Effects of temperature on 'Candidatus Liberibacter solanacearum' and zebra chip potato disease symptom development. Plant Dis 96:18-23

Munyaneza JE, Sengoda VG, Sundheim L, Meadow R (2014) Survey of 'Candidatus Liberibacter solanacearum' in carrot crops affected by the psyllid Trioza apicalis (Hemiptera: Triozidae) in Norway. J Plant Pathol 96:397-402

Murray HG, Thompson WF (1980) Rapid isolation of high molecular weight DNA. Nucleic Acids Res 8:4321-4325

Nelson WR, Fisher TW, Munyaneza JE (2011) Haplotypes of 'Candidatus Liberibacter solanacearum' suggest long-standing separation. Eur J Plant Pathol 130:5-12

Nelson WR, Sengoda VG, Alfaro-Fernández A, Font MI, Crossling JM, Munyaneza JE (2012) A new haplotype of "Candidatus Liberibacter solanacearum" identified in the Mediterranean region. Eur J Plant Pathol 135:633-639

Nelson WR, Wulff NA, Bové JM (2015) Intragenomic homogeneity on Liberibacter 16S rDNA confirms phylogeny and explains ecological strategy. bioRxiv. https://doi.org/10.1101/016188

R Core Team, 2016. R: A language and environment for statistical computing. R Foundation for Statistical Computing, Vienna, Austria. https://www.R-project.org/

Ravindran A, Levy J, Pierson E, Gross DC (2011) Development of primers for improved PCR detection of the potato zebra chip pathogen, 'Candidatus Liberibacter solanacearum'. Plant Dis 95:1542-1546

Secor GA, Rivera VV, Abad JA, Lee IM, Clover GRG, Liefting LW, Li X, De Boer SH (2009) Association of 'Candidatus Liberibacter solanacearum' with the zebra chip disease of potato established by graft and psyllid transmission, electron microscopy, and PCR. Plant Dis 93:574-583

Tahzima R, Maes M, Achbani EH (2014) First report of 'Candidatus Liberibacter solanacearum' on carrot in Africa. Plant Dis 10:1426

Tamura K, Stecher G, Peterson D, Filipski A, Kumar S (2013) Mega6: Molecular evolutionary genetics analysis version 6.0. Mol Biol Evol 30:2725-2729

Teresani GR, Bertolini E, Alfaro-Fernández A, Martínez C, Tanaka FAO, Kitajima EW, Roselló M, Sanjuán S, Ferrándiz JC, López MM, Cambra M, Font MI (2014) Association of 'Candidatus Liberibacter solanacearum' with a vegetative disorder of celery in Spain and development of a real-time PCR method for its detection. Phytopathology 104:804-811

Teresani GR, Hernández E, Bertolini E, Siverio F, Marroquín C, Molina J, Hermoso de Mendoza A, Cambra M (2015) Search for potential vectors of 'Candidatus Liberibacter solanacearum': population dynamics in host crops. Span J Agric Res 13:e10-002

Wen A, Johnson C, Gudmestad NC (2013) Development of a PCR assay for the rapid detection and differentiation of 'Candidatus Liberibacter solanacearum' haplotypes and their spatiotemporal distribution in the United States. Am J Potato Res 90:229-236 